\title{
Optimization of Learning Effectiveness through the Learning Environment and Learning Motivation for Students
}

\author{
Masduki Ahmadi \\ DOI: $10.35445 /$ alishlah.v13i3.617
}

\section{Info Artikel}

Keywords:

Learning Environment; Learning Motivation; Learning Effectiveness

Kata kunci:

Lingkungan Belajar;

Motivasi Belajar;

Efektivitas Pembelajaran

\section{Abstract}

This study aims to analyze the impact given by the learning environment and learning motivation on the student learning effectiveness at As-Syafiiyah Islamic University. This research is based on the problem that education in Indonesia is currently paralyzed, including higher education at universities, one of which is the As-Syafiiyah Islamic University. A quantitative methodology is a technique used in this study with the primary model of multiple linear regression. Using the Slovin formula, the research participants were 340 students from various study programs at the As-Syafiiyah Islamic University. Research data was obtained through a questionnaire distributed online. Statistical calculations were carried out using SPSS 25, and the hypothesis test used the t-test and f-test. It was revealed that: 1) the learning environment significantly and positively affects the learning effectiveness at As-Syafiiyah Islamic University; 2) the learning motivation significantly and positively affects the learning effectiveness at As-Syafiiyah Islamic University, and 3)both of learning environment and learning motivation impact student learning effectiveness at As-Syafiiyah Islamic University by $77.5 \%$. This research is expected to have implications for improving the quality of education during the pandemic. In particular, it can illustrate how important the learning environment and learning motivation are to the university's effectiveness.

\begin{abstract}
Abstrak
Penelitian ini bertujuan untuk menganalisis pengaruh lingkungan belajar dan motivasi belajar terhadap efektivitas belajar mahasiswa di Universitas Islam As-Syafiiyah. Penelitian ini diangkat dari permasalahan bahwa saat ini pendidikan di Indonesia sedang lumpuh termasuk pendidikan tinggi di universitas yang mana salah satunya adalah Universitas Islam As-Syafiiyah. Metodologi kuantitatif merupakan teknik yang digunakan dalam penelitian ini dengan model utama regresi linier berganda. Dengan menggunakan rumus Slovin, didapat partisipan penelitian sebanyak 340 mahasiswa dari berbagai program studi di Universitas Islam As-Syafi'iyah. Data penelitian didapat dengan melalui kuesioner yang disebarkan secara online. Perhitungan statistik dilakukan dengan menggunakan SPSS 25, dan uji hipotesis menggunakan uji-t dan uji-f. Diungkapkan bahwa: 1) lingkungan belajar berpengaruh secara signifikan dan positif terhadap efektivitas pembelajaran di Universitas Islam As-Syafiiyah; 2) motivasi belajar berpengaruh positif dan signifikan terhadap efektivitas belajar di Universitas Islam As-Syafiiyah, dan 3) lingkungan belajar dan motivasi belajar berpengaruh positif terhadap efektivitas belajar mahasiswa di Universitas Islam As-Syafiiyah sebesar 77,5\%.
\end{abstract}


Penelitian ini diharapkan dapat berimplikasi terhadap meningkatnya kualitas pendidikan di masa pandemi khususnya dapat memberikan gambaran seberapa pentingnya lingkungan belajar dan motivasi belajar terhadap efektivitas pembelajaran kepada pihak univeristas.

\section{INTRODUCTION}

Education that is carried out in schools is usually in the form of knowledge transfer from teachers to students. This activity is usually called learning. The success of the learning process is influenced by several factors, one of which is the effectiveness of the learning itself. Mulyasa stated that effectiveness is the suitability between people who carry out tasks with the targets aimed at and how an organization manages to get and utilize resources to achieve operational goals (Mulyasa E. , 2010). At the same time, the effectiveness of learning is a measure of the success of an interaction process between students and between students and educators in an educational situation to achieve learning objectives (Rohmawati, 2015). Learning can usually be said to be effective if the learning objectives can be achieved. The more learning objectives are achieved, it can be said that learning is very effective.

At this time, Indonesia is facing a period of the Covid-19 pandemic in which it has paralyzed several sectors, including education in universities. Learning is recommended to be carried out online, so there is no contact between individuals and others. Distance learning has also been implemented for a long time, which causes students and lecturers to get used to this learning model. This significant change certainly affects learning and its effectiveness as an activity that is routinely undertaken every day. Currently, students must be able to undergo learning from home without meeting face to face with lecturers. This is undoubtedly a challenge for students and lecturers alike. Due to the separation of students and lecturers throughout the learning process, instructors are unable to directly oversee student actions during the learning process (Sadikin \& Hamidah, 2020). Unlike face-to-face learning, where the lecturer can directly supervise students in taking part in learning in the classroom. This is one of the drawbacks of online learning. In a modern world like today, sending information from teachers to students is ineffective (Liu et al., 2020). This is because various factors will hamper the delivery of remote information.

One of the universities in Indonesia that have implemented online learning is As-Syafiiyah Islamic University. As a private university, As-Syafiiyah Islamic University still has to follow government regulations that require learning to be done online. Of course, this is a challenge for the university because online learning has just been implemented. This difficulty arises as a result of the university's lack of preparation in integrating online learning. Therefore, this research is expected to provide solutions related to the problems currently being faced by Indonesian education, especially learning at the As-Syafiiyah Islamic University.

One of the factors that influence the effectiveness of learning during a pandemic is the learning environment. The use of online learning will be very effective if it fulfills the essential components of learning which is very good if it is integrated with the learning environment so that it can become online learning that is integrated with the environment so that it can generate positive feelings (Oktavian \& Aldya, 2020). This means that one of the variables deciding the effectiveness of a lesson will be the learning environment and how well it can operate. The environment is around, which has a specific meaning and influence on the individual (Noviati et al., 2019). Meanwhile, according to Nurastanti, Ismail, and Sukirman, the learning environment is a condition or situation around the environment where students learn that can affect students' process and learning outcomes (Nurastanti et al., 2019). This means that the learning environment is all conditions around students 
where these conditions will affect the learning that is being carried out. Pratono and Minarni conveyed a similar opinion that a learning environment is a place for learning activities to take place that has external influences on the sustainability of these activities (Partono \& Minarni, 2007). So learning environment is the situations surrounding students that affect the learning process and the students themselves.

The learning environment during this pandemic was not a university environment as usual, but an environment where students were in access to online learning. The learning environment can be at home or in another place. Such a learning environment, of course, is different from a university environment where all students are influenced by the same environment, namely in the classroom in the college itself. A different environment currently influences every student because basically, they are not facing to face with the lecturer directly. This, of course, will also affect the effectiveness of student learning. That's because not all student learning environments are learning environments that support the learning process. In a supportive learning environment, all students must own if they want to achieve effective learning. If the learning environment conditions are very supportive, students will be more enthusiastic in the learning process (Aini \& Taman, 2012). This enthusiasm for students is a reflection of the student's motivation to learn.

Motivation to learn is another factor that affects the effectiveness of learning besides the learning environment. Motivation contains three main components, namely needs, goals, and encouragement (Susilo, 2012). According to Dimyati, learning motivation is a mental drive that drives and directs human behavior, including learning behavior (Dimyati \& Mudjiono, 2006). This means that learning motivation is a factor that encourages a person to continue learning. If a person does not have a high motivation to learn, his desire to continue learning can be interpreted as decreasing. Almost the same as the previous opinion, Sadirman stated that learning motivation is a set of driving forces that exist between students so that a desire to learn arises (Sadirman, 2011). In order to accomplish an objective, inspiration plays an essential part in underlying the diverse attitudes and activities of students interested in such conditions (Rafiola et al., 2020). Motivation is an encouragement that comes from within and outside the individual to achieve certain goals (Darmawati, 2017). From several previous statements, it can be concluded that learning motivation is the desire and encouragement from within students to make more efforts to achieve learning goals.

Motivation is an essential component needed in the learning process because it can encourage students to effectively carry out it (Sulistiyarini \& Sukardi, 2016). When a student has high learning motivation, the learning process will also run better. This is because learning motivation plays an essential role in receiving the learning currently being carried out. Motivation is of particular concern because of its important role in students learning (Tohidi \& Jabbari, 2012). Surwantini stated that if there is no motivation to learn in students, learning activities will not be optimal because they will be lazy or bored (Surwantini, 2016). When learning activities are not optimal, this means that the effectiveness of learning is not optimal either.

This research was conducted during a pandemic which caused differences in the learning being studied. Several previous studies only discussed the effectiveness of conventional learning. However, in this study, the learning in question is distance learning, which also reduces learning effectiveness. As a country carrying out face-to-face learning processes, Indonesia is certainly a little surprised by this change in pattern. This has an impact on teachers, students, and schools in implementing effective learning. This is an important point that distinguishes this study from other studies.

Looking at some of these problems, this research aims to determine the effects of the learning environment and motivation on online learning effectiveness during the Covid-19 pandemic. This analysis aims to determine how to optimize online learning effectiveness during the Covid-19 pandemic today by considering the learning environment and learning motivation as influencing factors. It is hoped that the results of this research will be useful considering that all learning was 
carried out online during the pandemic and was something new for the world of education in Indonesia. The hypotheses of this research include: 1) The learning environment has a significant and positive effect on the effectiveness of learning; 2) Learning motivation has a significant and positive effect on the effectiveness of learning and; 3) The learning environment and learning motivation have an influence on the effectiveness of learning.

\section{METHODS}

Research A quantitative methodology is the technique used in this study with the primary multiple linear regression model. In this research, participants were 340 students from various study programs at As-Syafi'iyah Islamic University. A closed questionnaire was used to obtain the information. Hypothesis testing, in this case, would employ the t-test to calculate the independent variable's influence and the F-test to jointly determine the independent variable's effect on the dependent variable. Meanwhile, several test stages were carried out as pre-requisites for analysis before conducting multiple linear regression analyses. Following the completion of all pre-requisite analytical tests, the research will proceed by determining the equation of the multiple linear regression model for this study as well as the coefficient of determination to determine how much the independent variable influences the dependent variable. All statistical tests in this study were carried out with the help of SPSS version 25 software.

This research has many limitations in its implementation in connection with the Covid-19 pandemic, so there are still many shortcomings in this study, especially in the data collection process using only online questionnaires. Therefore, if there is research in the future that deals with comparable topics, it would be better to take more significant numbers of respondents. Also, data collection can be done by observation so that the information obtained is accurate.

\section{FINDINGS AND DISCUSSION \\ Analysis Requirement Test}

1. Normality Test

Table 1. Kolmogorov-Smirnov Normality Test

\begin{tabular}{llr}
\hline & & \multicolumn{2}{c}{$\begin{array}{c}\text { Unstandardized } \\
\text { Residual }\end{array}$} \\
\hline $\mathrm{N}$ & & 340 \\
Normal Parameters & Sean & .0000000 \\
& Std. Deviation & 6.08022171 \\
Most Extreme Differences & Absolute & .038 \\
& Positive & .031 \\
& Negative & -.038 \\
Test Statistic & & .038 \\
Asymp. Sig. (2-tailed) & & .200 \\
\hline
\end{tabular}

The normality test was performed after gathering data on the factors under consideration. The normality test is performed to determine whether or not the study data is usually distributed. A successful regression model is a model with normally distributed test results. The KolmogorovSmirnov method was used to calculate the normality test in SPSS version 25. It may be inferred that the data in this study were normally distributed based on the Asymp value. Sig. (2-tailed), namely $0.200>0.05$. 


\section{Linearity Test}

The linearity test is used to establish that the independent and dependent variables in research have a linear relationship. There are two independent variables (learning environment and motivation) and one dependent variable (learning effectiveness). This linearity test was calculated using SPSS version 25 .

Table 2. Learning Environment on Learning Effectiveness Linearity Test

\begin{tabular}{llccccc}
\hline & & $\begin{array}{c}\text { Sum of } \\
\text { Squares }\end{array}$ & Df & $\begin{array}{c}\text { Mean } \\
\text { Square }\end{array}$ & F & Sig. \\
\hline Between & (Combined) & 42963.40 & 61 & 704.318 & 15.414 & .000 \\
Groups & Liniearity & 39423.65 & 1 & 39423.65 & 862.77 & .000 \\
& Deviation from & 8 & & 8 & 4 & .089 \\
& Liniearity & 3539.742 & 60 & 58.996 & 1.291 & .089 \\
Within Groups & & 12702.953 & 278 & 45.694 & & \\
Total & & 55666.353 & 339 & & & \\
\hline
\end{tabular}

From the results, it can be shown that the learning environment (X1) significance value on the learning effectiveness variable $(\mathrm{Y})$ is 0.089 . Because 0.089>0.05, it can be inferred that the relationship between variables $\mathrm{X} 1$ and $\mathrm{Y}$ is linear.

Table 3. Learning Motivation on Learning Effectiveness Linearity Test

\begin{tabular}{llccccc}
\hline & & $\begin{array}{c}\text { Sum of } \\
\text { Squares }\end{array}$ & Df & $\begin{array}{c}\text { Mean } \\
\text { Square }\end{array}$ & F & Sig. \\
\hline Between & (Combined) & 39484.707 & 57 & 692.714 & 12.072 & .000 \\
Groups & & & & & & \\
& Liniearity & 35135.933 & 1 & 35135.933 & 612.319 & .000 \\
& $\begin{array}{l}\text { Deviation from } \\
\text { Liniearity }\end{array}$ & 4348.774 & 56 & 77.657 & 1.353 & .060 \\
Within Groups & & 16181.646 & 282 & 57.382 & & \\
Total & & 55666.353 & 339 & & & \\
\hline
\end{tabular}

From the results, it can be shown that the significance value of the learning motivation (X2) on the learning effectiveness variable $(\mathrm{Y})$ is 0.060 . Because $0.060>0.05$, it can be concluded that the relationship between variables $\mathrm{X} 1$ and $\mathrm{Y}$ is linear.

3. Multicollinearity Test.

The multicollinearity test aimed to assess if independent variables are correlated. A successful regression model is a model which has no signs of multicollinearity with the condition that the Tolerance value is $>0.10$ and the VIF value $<10.00$. The multicollinearity test was carried out using SPSS version 25 .

Table 4. Multicollinearity Test

\begin{tabular}{|c|c|c|c|c|c|c|c|}
\hline & $\begin{array}{c}\text { Unstandar } \\
\text { dized } \\
\text { B }\end{array}$ & $\begin{array}{c}\text { Coefficient } \\
\text { s Std. } \\
\text { Error }\end{array}$ & $\begin{array}{c}\text { Standardiz } \\
\text { ed } \\
\text { Coefficient } \\
\text { s Beta }\end{array}$ & $\mathrm{t}$ & Sig. & $\begin{array}{c}\text { Collinearit } \\
\text { y } \\
\text { Tolerance }\end{array}$ & $\begin{array}{c}\text { Statistics } \\
\text { VIF }\end{array}$ \\
\hline (Constant) & 7.643 & 2.755 & & 2.774 & .006 & & \\
\hline $\begin{array}{l}\text { Learning } \\
\text { Environment }\end{array}$ & .538 & .037 & .560 & 14.665 & .000 & .457 & 2.186 \\
\hline Learning Motivation & .378 & .038 & .382 & 9.988 & .000 & .457 & 2.186 \\
\hline
\end{tabular}

From the results, It must be said that the tolerance value is $0.457>0.10$. It ensures that there are no symptoms of multicollinearity in this study. In addition, the VIF value can be used to make 
judgments. Because the VIF value is $2.186<10.00$, It can be assumed that this study model has no signs of multicollinearity.

\section{Heteroscedasticity Test.}

The heteroscedasticity test in this research uses Rank Spearman's test with the basis for decision-making if the significance value or Sig. (2-tailed) is more significant than 0.05, then there is no heteroscedasticity problem. The heteroscedasticity test was carried out using SPSS version 25 .

Table 5. Heteroscedasticity Test

Unstandardized Residual

\begin{tabular}{llr}
\hline Learning Environment & Correlation Coefficient & .033 \\
& Sig. (2-tailed) & .548 \\
$\mathrm{~N}$ & 340 \\
Learning Motivation & Correlation Coefficient & .028 \\
& Sig. (2-tailed) & .601 \\
& $\mathrm{~N}$ & 340 \\
\hline
\end{tabular}

From the output, it can be seen that the Sig. (2-tailed) for the learning environment is 0.548, which is greater ( $>$ ) than 0.05. Then, the Sig. (2-tailed) for learning, motivation is 0.601, which is greater $(>)$ than 0.05 . Because the two obtained significance values are 0.05 , it can be indicated that there is no heteroscedasticity problem in this regression model.

\section{Multiple Linear Regression Model}

After completing all pre-analysis criteria for the multiple linear regression model, a test will be conducted to determine this study's multiple linear regression model.

\begin{tabular}{lc}
\multicolumn{2}{c}{ Table 6. Multiple Linear } \\
\multicolumn{1}{c}{ Variables } & Regression Analysis \\
& \\
\hline Constant & 7.643 \\
Learning Environment (X1) & 0.538 \\
Learning Motivation (X2) & 0.378 \\
\hline
\end{tabular}

Based on the findings, it can be deduced that the regression equation model used in this study is: $\mathrm{Y}=7.643+0.538+0.378$

\section{Table 7. Coefficient of Determination Value}

\begin{tabular}{cccc}
\hline $\mathbf{R}$ & R Square & Adjusted R Square & $\begin{array}{c}\text { Std. Error of } \\
\text { the Estimate }\end{array}$ \\
\hline 0.880 & 0.775 & 0.774 & 6.098 \\
\hline
\end{tabular}

Then also obtained the coefficient of determination from the equation. The coefficient of determination from this regression equation may be deduced from the data. The coefficient value measures how much the independent variable (X) influences the dependent variable simultaneously (Y). The coefficient of determination is 0.775 , or 77.5 percent, based on the findings collected. This suggests that the independent variable together influences the learning effectiveness by $77.5 \%$. Meanwhile, the other $\mathbf{2 2 . 5 \%}$ was influenced by other variables that were not researched. 


\section{Hypothesis Test}

1. T-test.

\begin{tabular}{ccc}
\multicolumn{2}{c}{ Table 8. T-test Result } \\
\hline Variable & T count & Sig. \\
\hline $\begin{array}{ccc}\text { Learning Environment } \\
\text { (X1) }\end{array}$ & 14.665 & $\begin{array}{c}\text { O.00 } \\
\text { o }\end{array}$ \\
Learning Motivation (X2) & 9.988 & $\begin{array}{c}0.00 \\
0\end{array}$ \\
\hline
\end{tabular}

It can be viewed from the results obtained that the independent variable (X) influences the learning effectiveness partially (independently). That can be shown from the significance value of each independent variable. The significance value of the learning environment variable is 0.00o, which is smaller $(<)$ than 0.05 . Also, the t value for the learning environment variable is 14.665 , which is greater $(>)$ than the $t$ (337) table, which is valued at 1.967. This shows that the environment of learning significantly positively affects learning effectiveness. Similarly, the learning motivation (X2) with a significance value lower than 0.05 , namely 0.000 . The t value of the learning motivation variable is 9,988 , which is even higher ( $>$ ) than the table $t$ (337), which is 1,967 . This shows that learn motivation significantly and positively affects learning effectiveness.

2. F-test

Table 9. F-test Result

\begin{tabular}{cccccc}
\hline Model & $\begin{array}{c}\text { Sum of } \\
\text { Squares }\end{array}$ & Df & $\begin{array}{c}\text { Mean } \\
\text { Square }\end{array}$ & F & Sig. \\
& & & 21566.915 & 579.935 & .000 \\
Regression & 43133.829 & 2 & 2158 & & \\
Residual & 12532.524 & 337 & 37.188 & \\
Total & 55666.353 & 339 & & \\
\hline
\end{tabular}

The result table concludes that the independent variable (X) influences learning effectiveness simultaneously from the result table. This is demonstrated by the significance value (Sig.) of o.ooo, which is less $(<)$ than 0.05 . The computed $\mathrm{F}$ value can also be used to make conclusions. The calculated $\mathrm{F}$ value is 579,935 , which is greater $(>)$ than the $\mathrm{F}(2,338)$ table, which is 3.022 . From these results, the conclusion can be drawn the independent variable (X) simultaneously influence the effectiveness of learning.

This research aims to recognize the impact that the learning environment and learning motivation have on students' learning effectiveness at As-Syafiiyah Islamic University. The results obtained indicate that the two independent variables affect the learning effectiveness simultaneously. All these are shown in the F-test significance value, which is equal to 0.000. This value is lower $(<)$ than 0.05 , so this means that the independent variable affects the learning effectiveness at the same time (simultaneously). The calculated $\mathrm{F}$ value, namely 579,935 , is also greater $(>)$ than the $\mathrm{F}$ table which is valued at 3.022. The effect of these two variables is $77.5 \%$ on the effectiveness of learning. This is indicated by the value of $\mathrm{R} 2=0.775$. It is possible to conclude that the two independent variables (simultaneously) greatly influence the student learning effectiveness at As-Syafiiyah Islamic University.

From the research results, it was also found that the learning environment affects the effectiveness of learning. This is demonstrated by a significance value lower than 0.05, namely 0.000. Also, the t value for the learning environment variable is 14,665 , which is greater $(>)$ than the $t$ (337) table, which is 1.967. These findings revealed that the learning environment has a strong and positive impact on learning effectiveness. This means that when the learning environment is good, learning effectiveness will be even higher. 
This result is in line with the research conducted by Wahyudi et al. entitled The Effect of Teacher Readiness and Learning Environment on Learning Effectiveness at SMK Kristen 1 Surakarta. Where obtained from the research results, the value of the t-test coefficient is 0.024 , which is smaller than 0.05. This significantly influences student learning environment variables on the teaching and learning process (Wahyudi et al., 2013). These results indicate that the learning environment indeed influences the effectiveness of learning. Conditions that are genuinely conducive and support the smooth teaching and learning process are requirements for effective learning (Anggraini et al., 2017). Students' learning environment during a pandemic has a significant impact on how learning can run effectively. Online learning through media such as video, audio, or online interaction between educators and students has better learning effectiveness than when students learn face-to-face (traditional) classes (Chou \& Liu, 2005). This can mean that even though almost every college is currently implementing online learning, learning can still be effective. Indeed, currently, the learning environment for each student is different depending on how the physical and social environment in which they participate in online learning. However, effective learning also still depends on how a lecturer creates an appropriate learning atmosphere for each student.

During a pandemic, how good the learning environment depends on how educators or lecturers provide teaching materials and materials suitable for online learning. With the creativity that every educator must have today, it is hoped that solutions can be used in online learning. Innovation is also expected to be continuously improved in every lesson so that learning does not run tediously and runs effectively. The implication is that policymakers, administrative staff, and educators must strive to provide a good and satisfying learning environment in physical and social environments such as communication. A detailed needs analysis is required. This was done with the hope of increasing the effectiveness of learning (Mutlu \& Yıldırım, 2019). With the teacher's role as a good facilitator fulfilled, of course, a good learning environment will be achieved, and the effectiveness of learning can increase.

The following results show that learning motivation also influences the effectiveness of learning. The significance value of $0.000<0.05$ and the $t$ value of 9,988> $t$ (337) of the table of 1,967 show that an impact gives by learning motivation on learning effectiveness. According to this research, learner motivation has a significant and positive impact on learning effectiveness. It ensures that when the motivation to learn increases, the effectiveness of learning will also increase.

Based on these findings, it can be concluded that learning motivation is one of the things that affect how far learning can go effectively. Motivation to learn on the student in school is quite important and can impact the learning effectiveness because motivation can enhance their drive to attain optimum objectives (Bakar, 2014). This means that when a student has high learning motivation, he will achieve the learning objectives more optimally than students who have low learning motivation. Motivation to learn and generate a stronger desire from students in the learning process also encourage students to achieve something. The effectiveness of learning is very dependent on the interests, needs, and roles of the students themselves, all of which are part of the characteristics of someone who has motivation (Atma et al., 2021). When they have the motivation to learn in themselves, they will try harder to excel academically. This also causes learning to be more effective because students with high learning motivation will find it easier to try to receive every instruction and command from educators. This makes there is no repetition of differences in perceptions between educators and students.

Several internal influence the effectiveness of the learning process, one of which is learning motivation and the task of an educator is to create conditions that can guide students to be motivated to learn (Yunita, 2017). This means that students' learning motivation cannot be separated from the 
role of a teacher in improving. As previously stated, a teacher must create conditions in which students have a high desire to learn. In other words, an educator must know what can increase learning motivation in his students. Learning during this pandemic can certainly be a challenge for educators because it has to raise students' morale and motivation indirectly. When online learning feels boring and heavy for students, that's where the role of an educator is needed.

\section{CONCLUSIONS}

Based on the results of this study, the researcher also suggests several research implications that can be applied to the higher education learning process; 1) For effective learning to be achieved, the learning environment of students must support both the physical and social environment. The role of lecturers and universities is very much needed in this case. Lecturers can become facilitators in creating a good learning environment, such as building interpersonal communication. Also, the higher education institution can provide support in the form of facilitating learning needs. This could be an internet facility which is good enough for any student who finds it difficult. Although there are still some things that cannot be changed too much, such as each student's ability towards learning facilities, 2) Learning motivation must also be considered because this is one of the variables affecting student learning effectiveness. This increase in learning motivation can also be done with the role of a lecturer. Lecturers can create a competitive learning atmosphere so that each student can be more motivated to learn. Conclusion: there must be something that is achieved in every learning process to raise the desire of every student to follow learning harder.

After this research is carried out, it is hoped that it can guide every education sector, significantly higher education, in maximizing the online learning that is carried out. By ensuring that students' learning environment remains conducive and their motivation to learn is also high, then according to the results of this study, learning will run more effectively. It is also hoped that this research can reference future research that takes the same focus.

\section{ACKNOWLEDGMENT}

Thanks to all the research teams who assisted in this research process and Jakarta State University for their support.

\section{REFERENCES}

Aini, P. N., \& Taman, A. (2012). Pengaruh Kemandirian Belajar Dan Lingkungan Belajar Siswa Terhadap Prestasi Belajar Akuntansi Siswa Kelas Xi Ips Sma Negeri 1 Sewon Bantul Tahun Ajaran 2010/2011. Jurnal Pendidikan Akuntansi Indonesia. https://doi.org/10.21831/jpai.v10i1.921

Anggraini, Y., Patmanthara, S., \& Purnomo, P. (2017). Pengaruh lingkungan belajar dan displin belajar terhadap hasil belajar kompetensi keahlian elektronika industri di sekolah menengah kejuruan. Jurnal Pendidikan.

Atma, B. A., Azahra, F. F., \& Mustadi, A. (2021). Teaching style, learning motivation, and learning achievement: Do they have significant and positive relationships? Jurnal Prima Edukasia. https://doi.org/10.21831/jpe.v9i1.33770

Bakar, R. (2014). the Effect of Learning Motivation on Student'S Productive Competencies in Vocational High School, West Sumatra. International Journal of Asian Social Science.

Chou, S. W., \& Liu, C. H. (2005). Learning effectiveness in a Web-based virtual learning environment: A learner control perspective. In Journal of Computer Assisted Learning. https://doi.org/10.1111/j.1365-2729.2005.00114.x

Darmawati, J. (2017). Pengaruh Motivasi Belajar Dan Gaya Belajar Terhadap Prestasi Belajar Ekonomi Siswa Sma Negeri Di Kota Tuban. Jurnal Ekonomi Pendidikan Dan Kewirausahaan. https://doi.org/10.26740/jepk.v1n1.p79-90

Dimyati, \& Mudjiono. (2006). Belajar dan Pembelajaran. Jakarta: Rineka Cipta.

Liu, Z. Q., Dorozhkin, E. M., Davydova, N. N., \& Sadovnikova, N. O. (2020). Co-learning as a new model of learning in a digital environment: Learning effectiveness and collaboration. 
International Journal of Emerging Technologies in Learning. https://doi.org/10.3991/ijet.v15i13.14667

Mulyasa, E. (2010). Implementasi Kurikulum Tingkat Satuan Pendidikan Kemandirian Guru dan Kepala Sekolah. Jakarta: Bumi Aksara.

Mutlu, G., \& Yıldırım, A. (2019). Learning Environment Perceptions and Student Background Variables as Determinants of Persistence in EFL Learning. SAGE Open. https://doi.org/10.1177/2158244019898805

Noviati, R., Misdar, M., \& Adib, H. S. (2019). Pengaruh Lingkungan Belajar Terhadap Tingkat Konsentrasi Belajar Siswa Pada Mata Pelajaran Akidah Akhlak Di Man 2 Palembang. Jurnal PAI Raden Fatah. https://doi.org/10.19109/pairf.v1i1.3010

Nurastanti, Z., Ismail, F., \& Sukirman, S. (2019). Pengaruh Lingkungan Belajar Di Sekolah Terhadap Hasil Belajar Siswa Pada Mata Pelajaran Fiqih Kelas Xi Madrasah Aliyah Negeri 1 Banyuasin. Jurnal PAI Raden Fatah. https://doi.org/10.19109/pairf.v1i1.3008

Oktavian, R., \& Aldya, R. F. (2020). Efektivitas Pembelajaran Daring Terintegrasi di Era Pendidikan 4.o. Didaktis: Jurnal Pendidikan Dan Ilmu Pengetahuan. https://doi.org/10.30651/didaktis.v20i2.4763

Pengaruh Disiplin Belajar Dan Lingkungan Keluarga Terhadap Hasil Belajar Ekonomi. (2007). Pengaruh Disiplin Belajar Dan Lingkungan Keluarga Terhadap Hasil Belajar Ekonomi. https://doi.org/10.15294/dp.v2i2.447

Pengembangan Model Pembelajaran Ipa Berbasis Masalah Untuk Meningkatkan Motivasi Belajar Dan Berpikir Kritis Siswa Smp. (2012). Journal of Primary Education. https://doi.org/10.15294/jpe.v1i1.58

Rafiola, R. H., Setyosari, P., Radjah, C. L., \& Ramli, M. (2020). The effect of learning motivation, self-efficacy, and blended learning on students' achievement in the industrial revolution 4.o. International Journal of Emerging Technologies in Learning. https://doi.org/10.3991/ijet.v15io8.12525

Rohmawati, A. (2015). Efektivitas Pembelajaran. Jurnal Pendidikan Usia Dini.

Sadikin, A., \& Hamidah, A. (2020). Pembelajaran Daring di Tengah Wabah Covid-19. BIODIK. https://doi.org/10.22437/bio.v6i2.9759

Sadirman. (2011). Interaksi dan Motivasi Belajar Mengajar. Jakarta: Raja Grafindo Persada.

Sulistiyarini, D., \& Sukardi, S. (2016). The Influence Of Motivation, Learning Styles, Teacher Leadership, And Teaching Intensity On Students' Leaning Outcomes. Jurnal Pendidikan Teknologi Dan Kejuruan. https://doi.org/10.21831/jptk.v23i2.12296

Surwantini, E. (2016). Efektivitas Penggunaan Media Visual Terhadap Motivasi Belajar Dan Prestasi Belajar Siswa Kelas Iii Sd Gugus 01 Imogiri, Bantul. Jurnal Penelitian Ilmu Pendidikan. https://doi.org/10.21831/jpipfip.v8i2.8273

Tohidi, H., \& Jabbari, M. M. (2012). The effects of motivation in education. Procedia - Social and Behavioral Sciences. https://doi.org/10.1016/j.sbspro.2011.12.148

Wahyudi, R., Santosa, S., \& Sumaryati, S. (2013). Pengaruh Kesiapan Guru Mengajar Dan Lingkungan Belajar Terhadap Efektivitas Pembelajaran Di Smk Kristen 1 Surakarta. Jupe Uns.

Yunita, L. (2017). The Learning Effectivity Of Chemistry Experimental Activity In Laboratorium Toward The Student's Learning Motivation. Jurnal Penelitian Dan Pembelajaran IPA. https://doi.org/10.30870/jppi.v3i1.1739 